\title{
Groundwater-surface water interactions, vegetation dependencies and implications for water resources management in the semi-arid Hailiutu River catchment, China - a synthesis
}

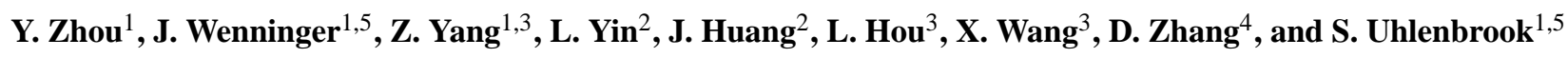 \\ ${ }^{1}$ UNSCO-IHE Institute for Water Education, P.O. Box 3015, 2601 DA, Delft, the Netherlands \\ ${ }^{2}$ Xi' an Center of Geological Survey, China Geological Survey No. 438, Youyidong Road, Xi' an, 710054, China \\ ${ }^{3}$ China University of Geosciences, Xueyuan Road 29, Beijing, 100083, China \\ ${ }^{4}$ Hohai University, Xikang Road 1, Nanjing, 210098, China \\ ${ }^{5}$ Delft University of Technology, Water Resources Section, P.O. Box 5048, 2600 GA, Delft, the Netherlands
}

Correspondence to: Y. Zhou (y.zhou@unesco-ihe.org)

Received: 24 October 2012 - Published in Hydrol. Earth Syst. Sci. Discuss.: 29 November 2012

Revised: 24 May 2013 - Accepted: 1 June 2013 - Published: 4 July 2013

\begin{abstract}
During the last decades, large-scale land use changes took place in the Hailiutu River catchment, a semiarid area in northwest China. These changes had significant impacts on the water resources in the area. Insights into groundwater and surface water interactions and vegetationwater dependencies help to understand these impacts and formulate sustainable water resources management policies. In this study, groundwater and surface water interactions were identified using the baseflow index at the catchment scale, and hydraulic and water temperature methods as well as event hydrograph separation techniques at the sub-catchment scale. The results show that almost $90 \%$ of the river discharge consists of groundwater. Vegetation dependencies on groundwater were analysed from the relationship between the Normalized Difference Vegetation Index (NDVI) and groundwater depth at the catchment scale and along an ecohydrogeological cross-section, and by measuring the sap flow of different plants, soil water contents and groundwater levels at different research sites. The results show that all vegetation types, i.e. trees (willow (Salix matsudana) and poplar (Populus simonii), bushes (salix Salix psammophila), and agricultural crops (maize - Zea mays)), depend largely on groundwater as the source for transpiration. The comparative analysis indicates that maize crops use the largest amount of water, followed by poplar trees, salix bushes, and willow trees. For sustainable water use with the objective of satisfying the water demand for
\end{abstract}

socio-economical development and to prevent desertification and ecological impacts on streams, more water-use-efficient crops such as sorghum, barley or millet should be promoted to reduce the consumptive water use. Willow trees should be used as wind-breaks in croplands and along roads, and drought-resistant and less water-use intensive plants (for instance native bushes) should be used to vegetate sand dunes.

\section{Introduction}

Arid and semi-arid areas occupy around one third of the terrestrial earth surface (Scanlon et al., 2006). In arid areas, water resources are extremely scarce and the environment is very fragile. Surface water resources are usually limited beside occasional flood events, and groundwater is the main source of water-sustaining stream flow and vegetation. Vegetation plays a crucial role in protecting against desertification. Sustainable use of groundwater resources is fundamental for the co-existence of human society and nature in arid and semi-arid areas. However, achieving sustainable use of groundwater remains a major challenge (Gleeson et al., 2012). The practice of using groundwater based on the "safe yield" policy has led to stream flow reduction and loss of wetlands and riparian ecosystems (Sophocleous, 2000). In a river basin where complex interactions exist between groundwater, surface water and ecosystems, the simplistic safe yield 
concept based on groundwater balance equations is not capable of delivering a sustainable groundwater-use plan. Sustainable use of groundwater requires balancing the water requirements for societal use, stream environmental flow, and terrestrial vegetation (Sophocleous, 2007; Zhou, 2009). The scientific challenges include quantifying groundwater and surface water interactions, estimating environmental flow requirements for groundwater dependent ecosystems, and to link these interdependencies to sustainable water resources management.

Groundwater and surface water interactions can be identified and quantified using a number of methods (Sophocleous, 2002; Kalbus et al., 2006; Brodie et al., 2007). Apart from traditional hydraulic methods, water temperature methods (Constantz et al., 2002; Constantz and Stonestrom, 2003) and hydrograph separation techniques using environmental isotopes as tracers (Sklash and Farvolden, 1979; Buttle, 1994) and combinations of different geophysical and tracer methods (Uhlenbrook et al., 2008; Wenninger et al., 2008) are widely used. Groundwater is an important source for terrestrial vegetations in arid and semi-arid areas (Miller et al., 2010). A number of methods have been developed for identifying vegetation dependency on groundwater (Eamus et al., 2006). Actual total evaporation rate (soil evaporation and transpiration) can be measured directly by the eddycorrelation method (Moreo et al., 2007). Transpiration rates of the vegetation can also be measured in situ with sap flow sensors (Granier, 1985; O'Grady et al., 2006), and the part of transpiration originating from groundwater can be estimated from diurnal groundwater level variations (White, 1932; Loheide et al., 2005; Butler et al., 2007; Lautz, 2008; Yin et al., 2013).

The Hailiutu River catchment is located within the Erdos Plateau in northwest China (Fig. 1). The catchment area is around $2645 \mathrm{~km}^{2}$, characterized by a continental semiarid climate. Land cover is dominated by sparsely vegetated sand dunes and cropland is only found in river valleys and flat areas on upland part of the catchment. The area suffers from frequent sandstorms, and farmland has been threatened by moving sand dunes. At the beginning of the 1980s, the Chinese government started an afforestation project called "Three North Forest Shelterbelts" (Wang et al., 2010). Since the year 2000, a project called "Return Farmland to Forest and Grassland" has being implemented (Wang et al., 2009). Meanwhile, large-scale development of natural resources (coal and natural gas) is taking place (Yin et al., 2011). Allocating scarce water resources for socio-economical development and maintaining ecosystem health must be based on scientific information. However, the groundwater-surface water interactions and vegetation dependencies on groundwater have not yet been systematically investigated. The implications of these multiple interactions on sustainable water resources management have not been analysed so far, and are poorly understood.

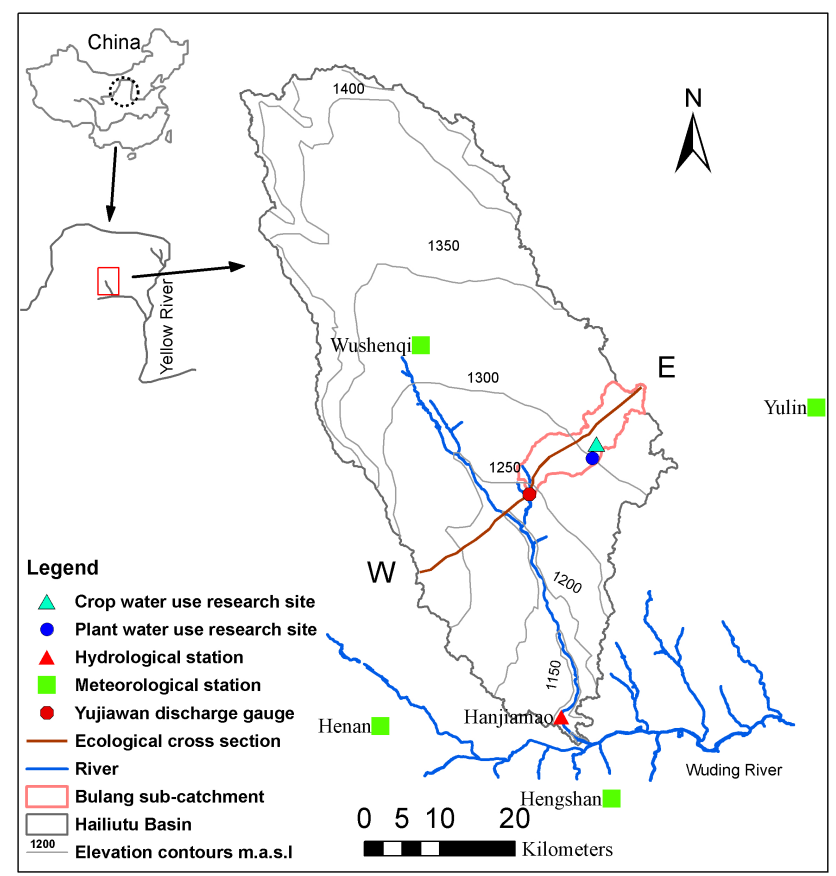

Fig. 1. Location of the Hailiutu catchment and measurement sites.

The objectives of this study are to analyse groundwatersurface water interactions and to identify vegetation dependency on groundwater in order to provide scientifically-based information for sustainable water resources management in the semi-arid Hailiutu catchment. Groundwater-surface water interactions were quantified using the baseflow index at the catchment scale, and using hydraulic, temperature and hydrograph separation methods at the sub-catchment scale. Vegetation dependencies on groundwater were identified using the relationship between groundwater depth and the Normalized Difference Vegetation Index (NDVI) (Lv et al., 2013) at the catchment scale and along an ecohydrogeological cross-section; using in situ sap flow, soil water and groundwater measurements at vegetation research sites were also taken. Conclusions from this study will have significant implications for land and water management in similar semiarid areas in northwest China and worldwide.

\section{Materials and methods}

\subsection{General research set-up}

This study targeted measurements using various methods to quantify groundwater-surface water interactions, and vegetation dependency on groundwater depth at different scales. Table 1 summarises the experimental methods, collected data, and methods for data analysis at different scales. 
Table 1. Measurements and data analysis methods.

\begin{tabular}{|c|c|c|c|c|}
\hline Research topics & Scales & Measuring methods & Data & Analysis methods \\
\hline \multirow{5}{*}{$\begin{array}{l}\text { Groundwater- } \\
\text { surface water } \\
\text { interactions }\end{array}$} & Catchment & Gauging station & $\begin{array}{l}\text { Daily river discharges } \\
1957 \text { to } 2007\end{array}$ & $\begin{array}{l}\text { From HYSEP baseflow } \\
\text { separation }\end{array}$ \\
\hline & \multirow[t]{4}{*}{$\begin{array}{l}\text { Sub- } \\
\text { catchment }\end{array}$} & Gauging station & $\begin{array}{l}\text { Hourly river stages and } \\
\text { river discharges in } 2011\end{array}$ & \multirow{2}{*}{$\begin{array}{l}\text { Isotope-aided } \\
\text { hydrograph } \\
\text { separation }\end{array}$} \\
\hline & & Isotope samples & $\begin{array}{l}\text { Oxygen-18 and Deuterium } \\
\text { in } 1-5 \text { July } 2011\end{array}$ & \\
\hline & & $\begin{array}{l}\text { Observation wells with } \\
\text { data loggers }\end{array}$ & $\begin{array}{l}\text { Hourly groundwater levels } \\
\text { in } 2010-2011\end{array}$ & Hydraulic gradient \\
\hline & & $\begin{array}{l}\text { Temperature sensors at } \\
\text { various depths }\end{array}$ & $\begin{array}{l}\text { Hourly temperature series } \\
\text { in 2010-2011 }\end{array}$ & $\begin{array}{l}\text { Steady-state } \\
\text { analytical solution }\end{array}$ \\
\hline \multirow{11}{*}{$\begin{array}{l}\text { Vegetation } \\
\text { dependency on } \\
\text { groundwater } \\
\text { depth }\end{array}$} & \multirow[t]{2}{*}{ Catchment } & $\begin{array}{l}\text { Landsat-5 Thematic } \\
\text { Mapper }\end{array}$ & NDVI in July 2010 & \multirow[t]{2}{*}{$\begin{array}{l}\text { Comparison and } \\
\text { regression analysis }\end{array}$} \\
\hline & & Well inventory & $\begin{array}{l}\text { Contour map of } \\
\text { groundwater depths in } \\
\text { July } 2010\end{array}$ & \\
\hline & \multirow[t]{2}{*}{$\begin{array}{l}\text { Cross- } \\
\text { section }\end{array}$} & $\begin{array}{l}\text { Landsat-5 Thematic } \\
\text { Mapper }\end{array}$ & NDVI in July 2010 & \multirow[t]{2}{*}{$\begin{array}{l}\text { Comparison and } \\
\text { correlation analysis }\end{array}$} \\
\hline & & Well inventory & $\begin{array}{l}\text { Groundwater depths in } \\
\text { July } 2010\end{array}$ & \\
\hline & \multirow{3}{*}{$\begin{array}{l}\text { In situ plant } \\
\text { water use } \\
\text { research } \\
\text { sites }\end{array}$} & Sap flow sensor & $\begin{array}{l}\text { Hourly sap flow velocity } \\
\text { in } 2011\end{array}$ & \multirow{3}{*}{$\begin{array}{l}\text { Water balance } \\
\text { computation and } \\
\text { correlation analysis }\end{array}$} \\
\hline & & $\begin{array}{l}\text { Time Domain } \\
\text { Reflectometry sensor }\end{array}$ & $\begin{array}{l}\text { Hourly soil water content } \\
\text { in } 2011\end{array}$ & \\
\hline & & $\begin{array}{l}\text { Observation wells } \\
\text { with data loggers }\end{array}$ & $\begin{array}{l}\text { Hourly groundwater levels } \\
\text { in } 2011\end{array}$ & \\
\hline & \multirow{4}{*}{$\begin{array}{l}\text { In situ crop } \\
\text { water use } \\
\text { site }\end{array}$} & Sap flow sensor & $\begin{array}{l}\text { Hourly sap flow velocity } \\
\text { in } 2011\end{array}$ & \multirow{4}{*}{$\begin{array}{l}\text { Water balance } \\
\text { computation and } \\
\text { correlation analysis }\end{array}$} \\
\hline & & $\begin{array}{l}\text { Time Domain } \\
\text { Reflectometry sensor }\end{array}$ & $\begin{array}{l}\text { Hourly soil water content } \\
\text { in } 2011\end{array}$ & \\
\hline & & Mini lysimeter & $\begin{array}{l}\text { Hourly soil evaporation } \\
\text { rate in } 2011\end{array}$ & \\
\hline & & $\begin{array}{l}\text { Observation wells with } \\
\text { data loggers }\end{array}$ & $\begin{array}{l}\text { Hourly groundwater levels } \\
\text { in } 2011\end{array}$ & \\
\hline
\end{tabular}

\subsection{Measurements for quantifying groundwater-surface water interactions}

The Hailiutu catchment was instrumented with meteorological and hydrological stations (Fig. 1). One meteorological station is located inside the catchment, and three other stations are located in the surrounding areas. All meteorological stations have measured daily precipitation, air temperature, pan evaporation, relative humidity and wind speed since 1961. A hydrological station is located at the outlet of the catchment and has measured daily river discharges since
1957; daily discharges from 1957 to 2007 were available for analysis.

A discharge gauging station was constructed at Yujianwan in the Bulang sub-catchment in 2010 (Fig. 1). The subcatchment area monitored by the discharge station is around $90 \mathrm{~km}^{2}$. An automatic water level recorder (e+ WATER L, Eijkelkamp, Giesbeek, the Netherlands) was installed to register water levels at hourly intervals. River discharges were measured with the salt dilution method, and a rating curve was established to convert the hourly water levels to hourly 
river discharges. The hourly river discharges have been measured since November 2010.

During a heavy rainfall event in 1-5 July 2011, water samples were taken every $30 \mathrm{~min}$ for the analysis of stable isotope (Oxygen-18 and Deuterium) concentrations. A total of 110 samples were collected. The isotope concentrations were used to separate the discharge hydrograph into direct surface runoff and baseflow components.

In a cross-section close to the discharge station, eight groundwater monitoring wells were constructed, and groundwater levels were recorded hourly with automatic data loggers (MiniDiver, Schlumberger Water Services, Delft, the Netherlands). The hydraulic gradient from measured groundwater and river water levels were computed to indicate the directions of groundwater and surface water exchanges.

In addition, four temperature sensors (HOBO Pro v2, Onset Computer Corporation, Bourne, USA) were installed below the riverbed at various depths to register hourly temperatures of the riverbed deposits. One sensor was placed on the riverbed to register the river water temperature. The temperatures have been measured since September 2010 and used to quantify groundwater-surface water interactions.

\subsection{Measurements for quantifying vegetation dependency on groundwater depth}

At the catchment scale, relations between the normalized difference vegetation index (NDVI) and groundwater depth were established to identify groundwater-dependent vegetations (Jin et al., 2008, 2011; Sun et al., 2008). A Landsat5 remote sensing image of 10 July 2010 , with a $30 \mathrm{~m}$ resolution was obtained from the Computer Network Information Center, Chinese Academy of Sciences (http://datamirror. csdb.cn/). The NDVI values were computed and classified for land cover types. During July 2010, field measurements of groundwater levels in the catchment were conducted at 46 sites. Historical groundwater level measurements were collected. A total of 540 measurements were used to construct a groundwater depth contour map. These data were used to analyse vegetation dependency on groundwater depth at the catchment scale and at an ecohydrogeological crosssection (Fig. 1).

The in situ plant water-use research site (Fig. 1) include a bush water use-site and a tree water-use site.

At the bush water-use research site, various instruments were installed to determine the salix bush (Salix psammophila) water use and rates of transpiration. The investigated salix was carefully selected so that it was representative of features such as size, number of branches, type and density of surrounding vegetation and micro-climatic conditions. The water use by salix was measured with a sap flow sensor (Flow 32 1K, Dynamax, Houston, USA). The meteorological variables were measured by a weather station. Rainfall was recorded by an automatic rain gauge (HOBO RG3, Onset Computer Corporation, Bourne, USA), soil water contents at various depths were measured by Time Domain Reflectometry sensor (TDR, Wintrase SEC Co. Ltd, USA), and groundwater table depths were measured by a monitoring well equipped with an automatic recorder (MiniDiver, Schlumberger Water Services, Delft, the Netherlands). Measurements were performed on an hourly basis between 29 May and 12 July 2011.

Instruments were installed at the tree water-use site to determine the tree water use of a willow (Salix matsudana) and a poplar tree (Populus simonii) and the water sources for transpiration. The examined trees were selected carefully; they are representative of the region in terms of physiological development, age, surrounding vegetation and micro-climatic conditions. The water use of tress was measured with sap flow sensors (FLGS-TDP XM1000, Dynamax, Houston, USA). Soil water contents were monitored using a TDR (Wintrase SEC Co. Ltd, USA) at various depths. Groundwater levels were measured hourly using an automatic recorder (MiniDiver) installed in a borehole under the tree. Measurements were performed on an hourly basis between 27 April to 7 November 2011.

An experimental site to investigate the crop water use was set-up in May 2011 (Fig. 1). Since the dominant crop in the catchment is maize (Zea mays), maize water use at a representative site was studied in further detail. The measurements included transpiration measurements of six maize stems monitored with sap flow sensors (Flow $321 \mathrm{~K}$ ), soil water content recorders (TDR, Wintrase SEC Co. Ltd, USA), mini lysimeters (organic glass; diameter: $102 \mathrm{~mm}$; depth: $108 \mathrm{~mm}$ ) to observe soil evaporation, groundwater levels (MiniDiver), and irrigation water application observations.

\section{Groundwater-surface water interactions}

\subsection{Catchment scale}

The automated hydrograph separation tool HYSEP (Sloto and Crouse, 1996) was used to separate baseflow from daily average river discharges using three baseflow separation methods: fixed interval, sliding interval, and local minimum. The separated daily baseflows obtained were very close and the average values were used for analysis. Annual averages of daily discharges and baseflow are plotted in Fig. 2. River discharges have decreased since the 1970s because of the construction of reservoirs and diversion works for irrigation. River discharges decreased to less than half of natural discharges during the 1990s due to the increase of crop areas (Yang et al., 2012). River discharges have recovered since 2000 to values comparable to the 1980s after the implementation of the policy to return farmland to nature (Yang et al., 2012).

The ratio of baseflow to total discharge is defined as baseflow index. From Fig. 2 it can be seen that the annual average baseflow constitutes 80 to $95 \%$ of the annual average total 

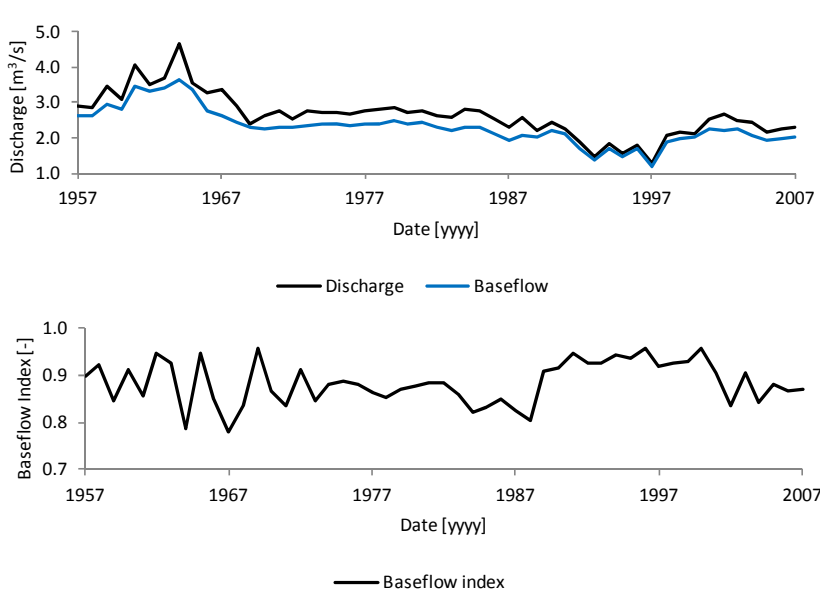

Fig. 2. Annual average river discharge, annual average baseflow, and annual baseflow index of the Hailiutu River at Hanjiamao station.

discharge. The average baseflow index for the last $40 \mathrm{yr}$ is around 0.88 , indicating that the vast majority of the stream flow is formed by groundwater discharge in the Hailiutu River. A recent study showed that the regional baseflow index was between 37.1 to $62.3 \%$ in the conterminous United States (Santhi at al., 2008). Only in a few catchments was the baseflow index between 80 to $90 \%$. The baseflow index in the Hailiutu catchment is comparatively high, indicating that the dominant hydrological process is groundwater recharge from precipitation by infiltration and delayed discharge to the river.

\subsection{Sub-catchment scale}

Groundwater levels decrease in general from the hillslope (Well_a) towards the flood plain (Well_b), at the riverbank (Well_c), and in the mid-river (Well_d) from 1 September to 28 October 2011 (Fig. 3), a clear indication of groundwater discharge towards the river during the whole measurement period.

Temperature measurements also indicate groundwater discharges to the river (Fig. 4). In winter, groundwater temperature is higher than the river temperature. Upward seepage of groundwater increases water temperature in the riverbed deposits, so that water temperature increases with the increase of depths. In summer, river temperature is much higher than the groundwater temperature; diurnal fluctuation of river temperature did not appear in the riverbed deposits, indicating also the upward seepage of groundwater.

Since the temperatures at various depths are stationary from 20 to 28 January 2011 (Fig. 4), the steady state heat transport equation satisfies (Bredehoeft and Papadopulos, 1965):

$\frac{\partial^{2} T}{\partial z^{2}}+\frac{c_{\mathrm{w}} \rho_{\mathrm{w}} v_{z}}{k} \frac{\partial T}{\partial z}=0$.

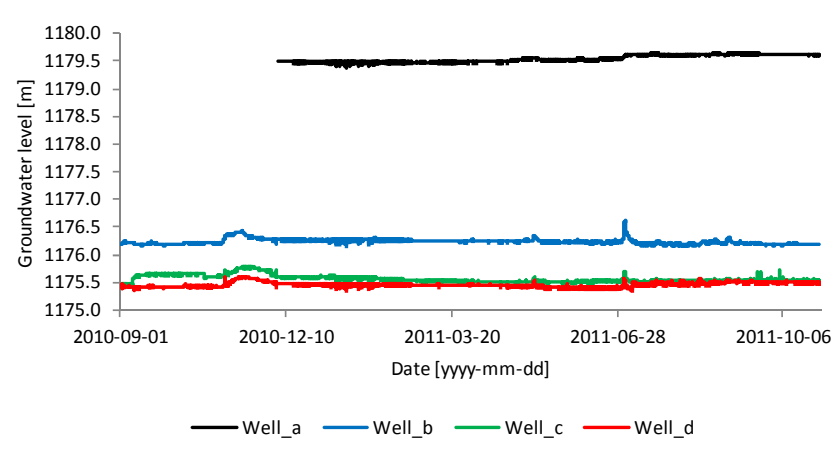

Fig. 3. Groundwater level measurements at Yujiawan cross-section. The distance between Well_a and Well_b is $284 \mathrm{~m}$; $22 \mathrm{~m}$ between Well_b and Well_c; and $4 \mathrm{~m}$ between Well_c and Well_d.

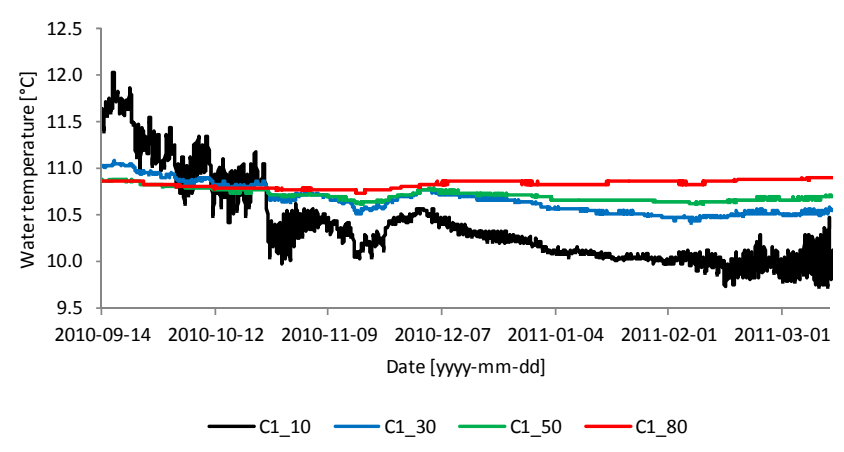

Fig. 4. Temperature measurements at various depths in the riverbed deposits at Yujiawan station: $\mathrm{C} 1 \_10$ at $10 \mathrm{~cm}$ depth, $\mathrm{C} 1 \_30$ at $30 \mathrm{~cm}$ depth, $\mathrm{C} 1 \_50$ at $50 \mathrm{~cm}$ depth, and $\mathrm{C} 1 \_80$ at $80 \mathrm{~cm}$ depth below the riverbed.

Boundary conditions are

$\left.T\right|_{z=0}=T_{0}$

$\left.T\right|_{z=L}=T_{L}$

where $T$ is the temperature; $T_{0}$ is the temperature at the top boundary; $T_{L}$ is the temperature at the bottom boundary (all in $\mathrm{K}) ; c_{\mathrm{W}}$ is the specific heat capacity of water $\left(\mathrm{J} \mathrm{kg}^{-1} \mathrm{~K}^{-1}\right)$; $\rho_{\mathrm{w}}$ is density of water $\left(\mathrm{kg} \mathrm{m}^{-3}\right) ; v_{z}$ is vertical groundwater flow velocity $\left(\mathrm{cm} \mathrm{s}^{-1}\right)$; and $k$ is the thermal conductivity of the soil-water matrix $\left(\mathrm{J} \mathrm{s}^{-1} \mathrm{~m}^{-1} \mathrm{~K}^{-1}\right)$.

The solution of the above equations is as follows (Arriaga and Leap, 2006):

$\frac{T_{z}-T_{0}}{T_{L}-T_{0}}=\frac{e^{\beta(z / L)}-1}{e^{\beta}-1}$

where

$\beta=\frac{c_{\mathrm{w}} \rho_{\mathrm{w}} v_{z} L}{k}$.

$L(\mathrm{~cm})$ is the vertical distance between the top and the bottom boundaries, and $z(\mathrm{~cm})$ is the depth of the temperature sensor below the top boundary. 
Table 2. Computed groundwater seepage velocity values.

\begin{tabular}{lrlr}
\hline Parameters & Value & Unit & $\begin{array}{r}\text { Computed } \\
\text { velocity } \\
\left(\mathrm{cm} \mathrm{d}^{-1}\right)\end{array}$ \\
\hline Density of water $\rho_{\mathrm{W}}$ & 1000 & $\mathrm{~kg} \mathrm{~m}^{-3}$ & \\
Specific heat capacity of water $c_{\mathrm{W}}$ & 41800 & $\mathrm{~J} \mathrm{~kg}^{-1} \mathrm{~K}^{-1}$ & \\
Thermal conductivity of fine sand $k^{*}$ & 1.8 & $\mathrm{~J} \mathrm{~s}^{-1} \mathrm{~m}^{-1} \mathrm{~K}^{-1}$ & -12.1 \\
Lower limit $k^{* *}$ & 1.4 & $\mathrm{~J} \mathrm{~s}^{-1} \mathrm{~m}^{-1} \mathrm{~K}^{-1}$ & -9.4 \\
Upper limit $k^{* *}$ & 2.2 & $\mathrm{~J} \mathrm{~s}^{-1} \mathrm{~m}^{-1} \mathrm{~K}^{-1}$ & -14.8 \\
\hline
\end{tabular}

* from Anibas et al. (2011); ${ }^{* *}$ from Stonestrom and Blasch (2003).

The average temperatures from 20 to 28 January 2011 at the 4 depths were used to solve Eq. (3) in order to identify the $\beta$ value. When the average temperature at $\mathrm{C} 1_{-} 10$ is defined as the top boundary $\left(T_{0}\right)$ and $\mathrm{C} 1 \_80$ as the bottom boundary $\left(T_{L}\right)$, the left side of Eq. (3) can be computed with the average temperatures in the temperature depth profile. The right side of Eq. (3) can be computed once the $\beta(-)$ is found. The sum of squared difference between the left and right sides of the Eq. (3) can be minimized to find the optimal value of $\beta$ as used by Boyle and Saleem (1979):

$\min F(\beta)=\sum_{z=1}^{L}\left[\frac{T_{z}-T_{0}}{T_{L}-T_{0}}-\frac{e^{\beta(z / L)}-1}{e^{\beta}-1}\right]^{2}$.

The Microsoft Excel Solver was used to perform the minimization and the optimal value of $\beta$ was found to be -2.2843 . The minimized sum of squared differences was only 0.00467 .

The vertical groundwater flow velocity $v_{z}\left(\mathrm{~cm} \mathrm{~d}^{-1}\right)$ can then be computed with Eq. (4) as

$v_{z}=\frac{k \beta}{c_{\mathrm{w}} \rho_{\mathrm{w}} L}$.

The parameters used and computed velocities are shown in Table 2. The velocity is negative, indicating upward groundwater discharge to the river. The estimated velocity is $12.1 \mathrm{~cm} \mathrm{~d}^{-1}$ corresponding to the fine sand of the river deposit. This value is on the high side of groundwater discharge velocities estimated by Anibas et al. (2011). The value is much larger than the infiltration velocity estimated by Arriaga and Leap (2006).

Groundwater contribution to river discharges during a heavy rainfall event on 1 to 5 July 2011 was estimated with the two-component tracer-based hydrograph separation technique (cf. Buttle, 1994, for methodology) using the stable isotope oxygen-18 $\left({ }^{18} \mathrm{O}\right)$ as a tracer (Fig. 5). The results indicate that the flood discharge consists of mainly increased groundwater discharge. Even during the peak time of the event, the discharge consists of more that $70 \%$ of pre-event water (i.e. groundwater). The dominance of pre-event water is also visible in the ascending and receding limbs of the

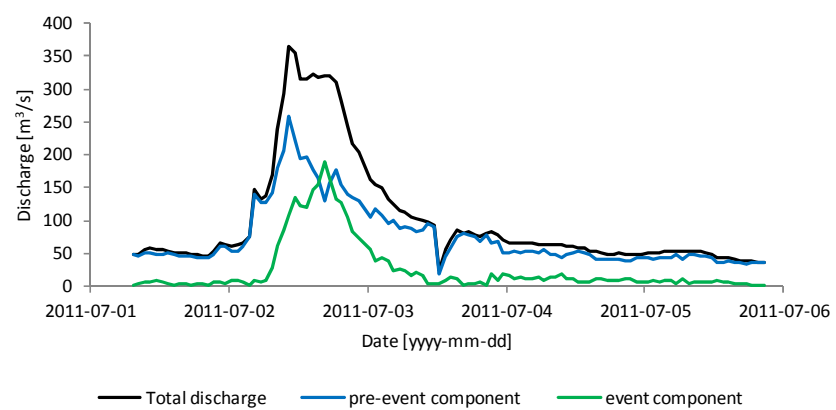

Fig. 5. Results of two-component hydrograph separation with Oxygen-18 as tracer at Yujiawan station.

stream hydrograph during the event. A rapid reaction of the pre-event runoff component could be caused by fast groundwater discharge from the near-stream riparian zone, whereas the delayed behaviour of the event water, showing the peak contribution after the maximum of the stream hydrograph, is likely due to a delayed contribution of surface runoff components. The two-component isotope-based hydrograph separation method has been applied in many cases studies worldwide and the pre-event water contribution to the total discharge was found varying greatly from 10 to $99 \%$ (Jones et al., 2006).

\section{Vegetation dependency on groundwater}

\subsection{Catchment scale}

Lv et al. (2013) investigated the dependency of vegetation on groundwater in the Hailiutu River catchment with NDVI data and observation data of groundwater depth. The statistical characteristics of NDVI values (mean, standard deviation and coefficient of skewness) change systematically in relation to the groundwater depth. Decreasing trends of both mean and standard deviation of NDVI values with increasing groundwater depth were found. The NDVI values of shrubs (Salix psammophila) and the dominant tree species (Salix matsudana and Populus tomentosa) decrease almost linearly with increasing groundwater depths. However, the 
NDVI values of grassland, represented by the meadow land cover type, were not sensitive to groundwater depth because of the shallow root systems. The relationship between NDVI and groundwater depth in farmlands was more complex because of the influences of human activities.

\subsection{At the ecohydrogeological cross-section}

The relationship between land surface elevation, groundwater depth, and vegetation distribution can be investigated along ecohydrogeological cross-sections. The ecohydrogeological cross-sections should run across the river valley from the water divide on one side to the water divide on other side. On these cross-sections, large variations of groundwater depths and vegetation types are expected. The investigated ecohydrogeological cross-section is running from the western water divide (W) across the Hailiutu River to the eastern water divide (E) (Fig. 1). The surface elevation, groundwater depth, and NDVI are shown in Fig. 6. The NDVI values in general follow the pattern of variations of groundwater depth. The correlation coefficient between NDVI value and groundwater depth was calculated to be -0.68 . At the west (W) and east water divides and at hilly areas in the catchment, the depth to the groundwater is large and NDVI is low, represented by a low density shrubland vegetation type. In the Bulang River and Hailiutu River valleys, groundwater levels are shallow, and NDVI is very high, as indicated by crops and trees. In local depressions on the west and east slope areas, groundwater levels are shallow; NDVI is also high, as indicated by upland crop areas mixed with wind-breaking trees. The cross-section indicates the dependency of the vegetation on groundwater depth in different geomorphologic locations.

\subsection{In situ ecohydrogeological research sites}

The cumulative sap flow of the measured salix bush and the willow tree were compared in relation to groundwater depths and the depletion of soil and groundwater storage in the dry period from 29 May to 12 June 2011 (Fig. 7).

At the bush water-use research site, the measured cumulative sap flow of the salix bush increased while groundwater level decreased. The correlation coefficient between the cumulative sap flow and groundwater depth is as high as 0.99 . The water balance method was used to compute the soil and groundwater storage depletions in the measured period. The total soil evaporation and transpiration of salix for the investigation period was computed to be around $41 \mathrm{~mm}$ $\left(2.9 \mathrm{~mm} \mathrm{~d}^{-1}\right)$, which could be separated in groundwater of $25 \mathrm{~mm}(60 \%)$ and soil water of $16 \mathrm{~mm}(40 \%)$. It became clear that salix uses more groundwater for transpiration in this dry period.

At the tree water-use research site, groundwater levels also decreased in response to the increase of the measured cumulative sap flow of the willow tree. The correlation coefficient between the cumulative sap flow and groundwater level
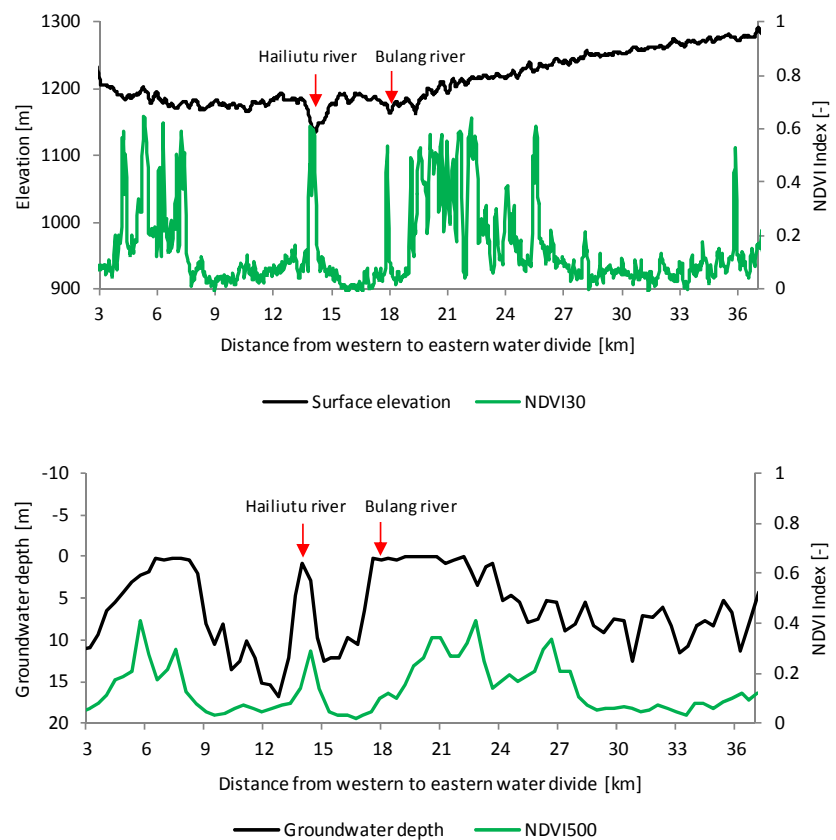

Fig. 6. Relations between NDVI30 (30 by $30 \mathrm{~m}$ grid values) and surface elevation, NDVI500 (500 by $500 \mathrm{~m}$ grid values) and groundwater depth along a ecohydrogeological cross-section in the Hailiutu River catchment.

is as high as 0.99 . For the same period, the total transpiration rate of the willow tree was calculated about $19.4 \mathrm{~mm}$ $\left(1.3 \mathrm{~mm} \mathrm{~d}^{-1}\right)$. The estimated groundwater storage depletion from groundwater level hydrograph amounts to $10.2 \mathrm{~mm}$ ( $53 \%$ of the transpiration rate), the depleted soil water stor-

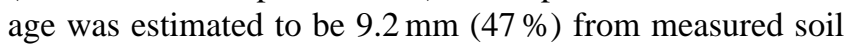
water contents. Therefore, it can be concluded that the willow tree is also a groundwater-dependent plant under the conditions prevailing in the Hailiutu River catchment.

\section{Comparison of water use by different plants}

\subsection{Comparison of sap flow velocities of poplar and willow trees}

Water scarcity is a natural phenomenon in the semi-arid Hailiutu River catchment. For water and soil conservation, it is very important to select plants which use little water for transpiration. Figure 8a compares the sap flow velocity of a representative willow tree with a representative poplar tree in the tree water-use research site at 3 measured periods in July, August, and September 2011. The average values of the plateau sap flow velocity (from 08:00 in the morning to 18:00 Local Beijing Time in the afternoon) of the willow tree were 9.0, $8.8,6.2 \mathrm{~cm} \mathrm{~h}^{-1}$, respectively, in July, August and September. The average sap flow velocities of the poplar tree were 12.3, $14.1,15.6 \mathrm{~cm} \mathrm{~h}^{-1}$, respectively, in July, August and September. The sap flow velocity of the poplar tree is larger than that 

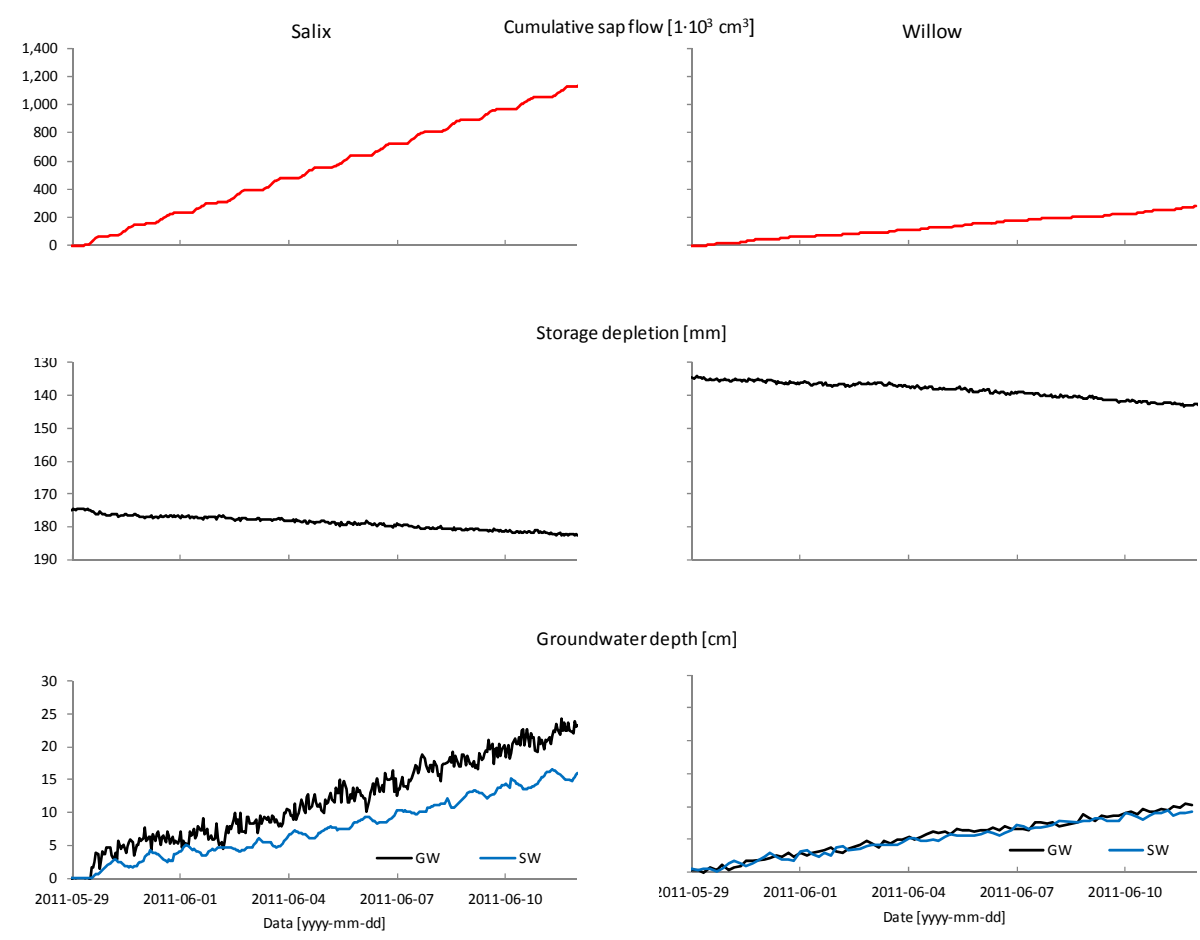

Fig. 7. Cumulative sap flow, groundwater depth, and depletion of soil and groundwater storage of the salix bush and the willow tree during the dry period from 19 May to 12 June 2011.

of the willow tree in all periods. Especially in September, the sap flow velocity of the willow tree is low, but the sap flow velocity of the poplar tree remains very high, more than two times higher than the willow tree. It can be concluded that the poplar tree uses more water than the willow tree in the Hailiutu catchment. Schaeffer et al. (2000) measured higher sap flow velocities of cottonwood and willow trees along active and abandoned stream channels of alluvial flood plains in the Southwest USA. They didn't find a significant difference in sap flow velocity between the cottonwood and willow trees. They found the transpiration rate of young forest patches adjacent to the active stream channel is higher than more successionally advanced patches on abandoned channels.

\subsection{Comparison of transpiration rates of maize and willow tree}

The transpiration rates of the maize crop and the willow tree were compared in July, August and September (Fig. 8b). The average values of the plateau transpiration rate (from 08:00 in the morning to 18:00 Local Beijing Time in the afternoon) of the maize crop were $13.9,11.9,3.8 \mathrm{~mm} \mathrm{~d}^{-1}$, respectively, in July, August and September. The average transpiration rates of the willow tree were $5.8,5.7,4.0 \mathrm{~mm} \mathrm{~d}^{-1}$, respectively, in July, August and September. In the growing periods from July to August, the transpiration rate of the maize is more than two times higher than that of the willow tree. Therefore, it can be concluded that maize uses more water than the willow tree, and most likely also more water than the poplar tree.

\subsection{Comparison of sap flow of salix bush and willow tree}

It is not straightforward to compare the water use of a salix bush with other plants since salix have various numbers of branches. Salix bushes with about 60 active branches are typical in the Hailiutu River catchment. Figure 8c compares diurnal variations of sap flow flux of a salix bush with 60 active branches with the sap flow flux of a willow tree for 15 days. The average daily sap flux was $116.6 \mathrm{~L} \mathrm{~d}^{-1}$ for the salix bush, and $51.4 \mathrm{Ld}^{-1}$ for the willow tree. It shows that the salix bush with 60 branches uses twice the amount of water of the willow tree. It is remarkable to see that the salix consumes more water than the willow tree since salix is perceived as a dry resistant plant and widely planted in the catchment as a measure for soil conservation.

\section{Implications for water resources management}

The presented results clearly demonstrate that both the surface water and the vegetation system strongly depend on groundwater. The water resources and ecosystem management requires essentially a sustainable groundwater resources management approach in the Hailiutu catchment. 

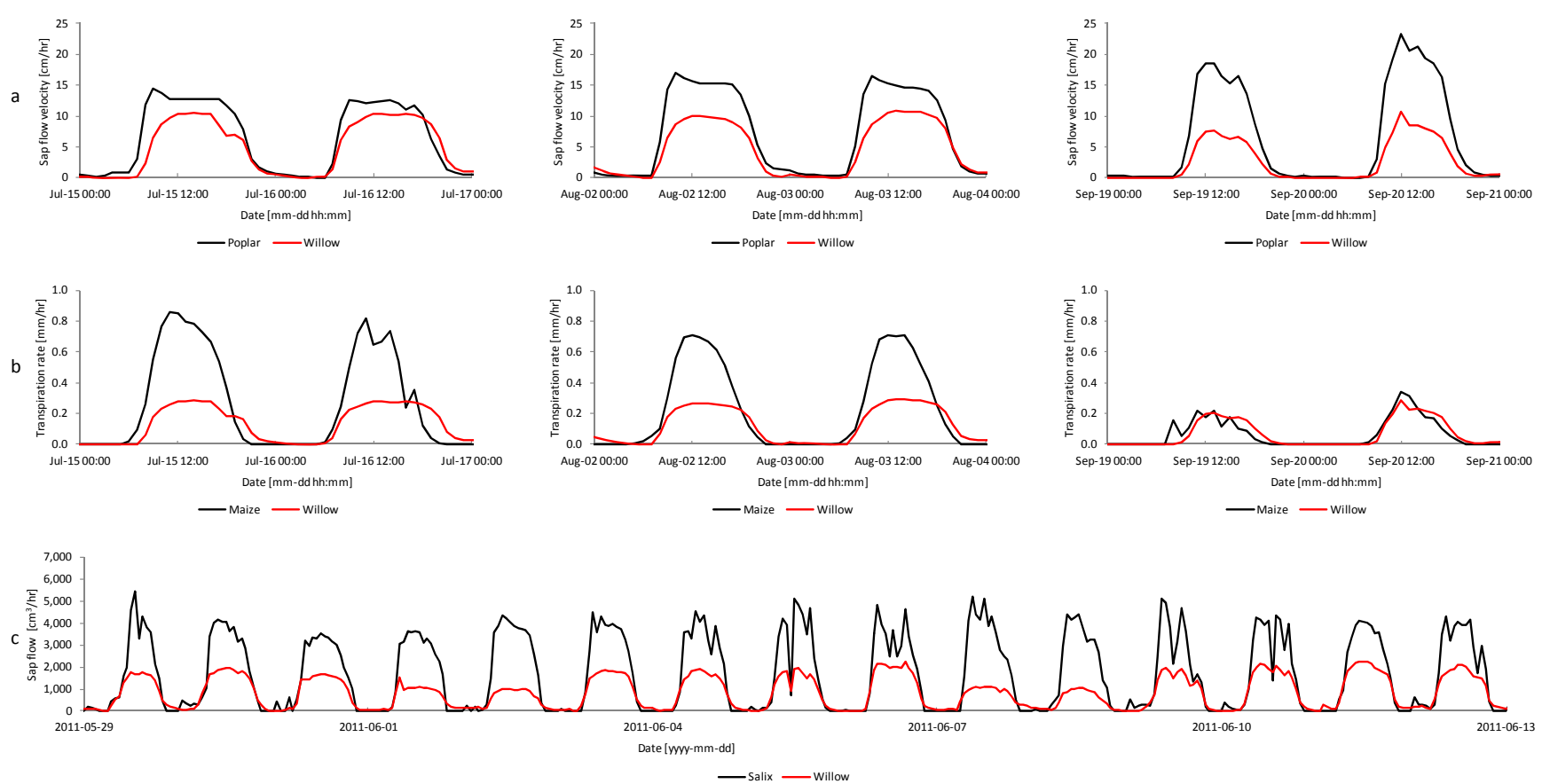

Fig. 8. Comparison of water use by different plants: (a) sap flow velocities between poplar and willow trees in July, August and September 2013; (b) transpiration rates between maize and willow in July, August and September 2011; (c) sap flow fluxes between salix bush and willow tree from 29 May to 12 June 2011.

The groundwater balance equation under natural conditions in the Hailiutu catchment can be formulated as the long-term average groundwater recharge, $R$, minus groundwater evaporation, $E$, equal to the baseflow component, $Q_{\mathrm{b}}$, of river discharge:

$R-E-Q_{\mathrm{b}}=0$.

Note that all water balance parameters in Eq. (7) have the unit $\mathrm{mm} \mathrm{a}^{-1}$, and the change of groundwater storage is assumed zero for long-term average. Under the steady-state abstraction, the new water balance equation becomes

$(R+\Delta R)-(E-\Delta E)-\left(Q_{\mathrm{b}}-\Delta Q_{\mathrm{b}}\right)-Q_{\mathrm{w}}=0$

where $Q_{\mathrm{w}}$ is the abstraction rate, $\Delta R$ is the increased recharge induced by pumping, $\Delta E$ is the decreased evaporation, and $\Delta Q_{\mathrm{b}}$ is the decreased groundwater discharge to the river. Replacing Eq. (7) in Eq. (8) results in Zhou (2009)

$Q_{\mathrm{w}}=\Delta R+\Delta E+\Delta Q_{\mathrm{b}}$

In the Hailiutu catchment, there is no possibility of the induced groundwater recharge by pumping, the abstraction rate has to be supplied by the decreased evaporation and decreased groundwater discharge to the river. The consumptive use of groundwater for irrigation $\left(Q_{\mathrm{w}}\right.$, gross abstraction minus return flow) reduces groundwater discharge to rivers. Therefore, river discharge is a good indicator of the water and vegetation management in the Hailiutu catchment. Maintaining sufficient river discharge with natural variations is not only important for the riparian ecosystem and local communities, but also for downstream water users. The water resources management objectives must satisfy both the environmental water use by vegetation and in-stream ecosystems as well as the water use for socio-economical development. Technical measures can be developed, including the minimization of consumptive water use by agricultural crops and water use by plants for vegetating sand dunes.

The research results show that the abstractions for irrigation and consumptive water use in the catchment is responsible for the reduction of the river discharges (cf. Yang et al., 2012). The findings from the crop water-use site show that maize consumes significant amounts of water (Hou et al., 2012). The total water use of maize during 159 growing days in 2011 was estimated to $607 \mathrm{~mm}$, which comprises precipitation of $157 \mathrm{~mm}(26 \%)$, irrigation water of $177 \mathrm{~mm}$ (29\%), and soil and groundwater of $273 \mathrm{~mm} \mathrm{(45 \% ).} \mathrm{In} \mathrm{the}$ river valley, irrigation water is taken directly from the river by diversions. In the upland, irrigation water is pumped from groundwater abstraction wells. Therefore, in order to reduce the consumptive water use, more dry resistant crops, such as sorghum, barley, and millet should be promoted. Fang et al. (2011) found also these crops are more suitable in semi-arid areas with an average annual precipitation of up to less than $300 \mathrm{~mm} \mathrm{a}^{-1}$. In Nebraska, seasonal maize water use was estimated to $658 \mathrm{~mm}$ (Kranz et al., 2008), while 

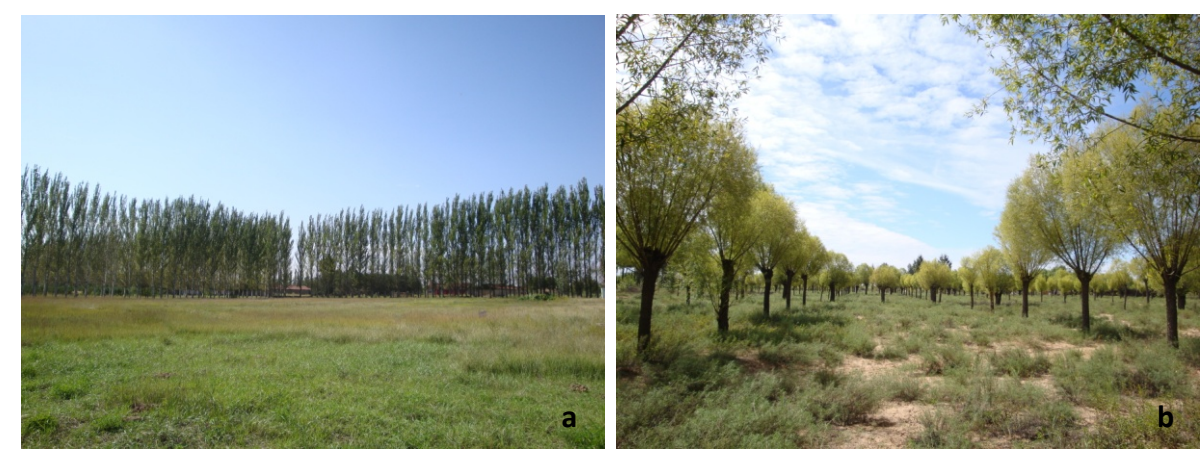

Fig. 9. Row of poplar (Populus simonii) trees (a) and willow (Salix matsudana) trees (b) as wind-breaking barrier, pictures taken in May 2010.
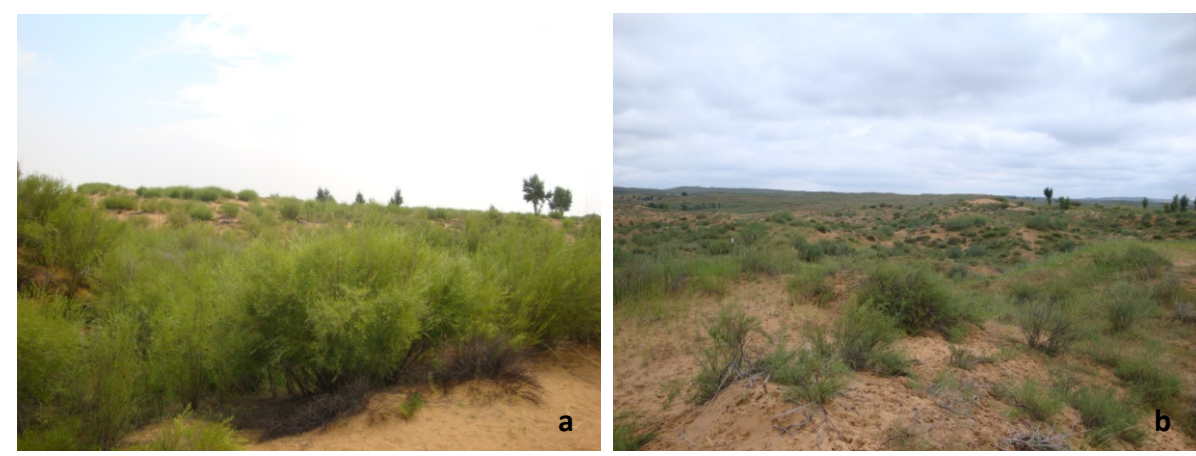

Fig. 10. Salix psammophila (a) and Artemisia Ordosica (b) planted for soil conservation, pictures taken in May 2010.
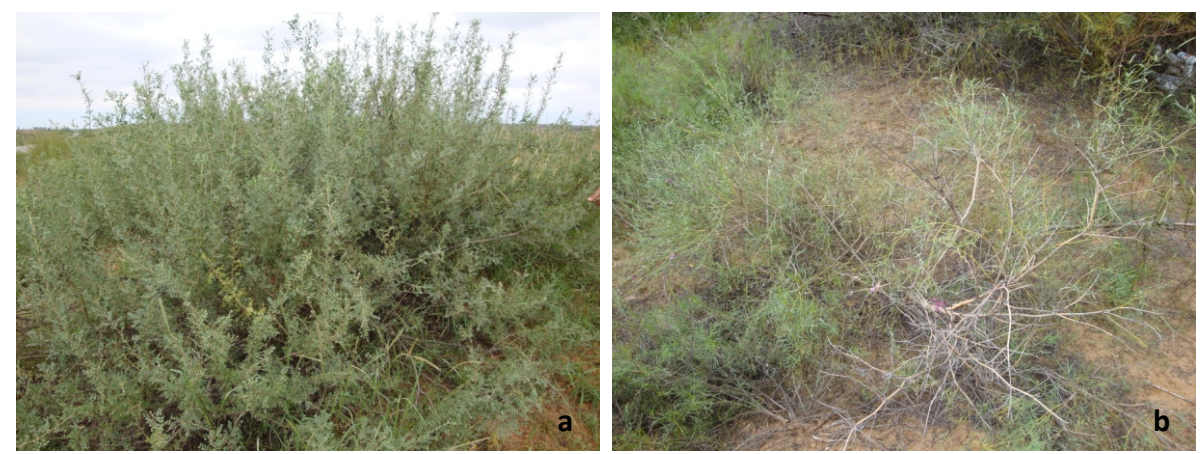

Fig. 11. Korshinsk Peashrub (a) and Hedysarum Laeve Maxim (b) planted for soil conservation, pictures taken in May 2010.

sorghum water use was around $530 \mathrm{~mm}$; thus, sorghum is a more water-use-efficient crop (CropWatch, 2012).

A rough estimate at catchment scale shows that almost $90 \%$ of precipitation is consumed by evaporation and transpiration of plants (Zhou, 2012). The presented research concluded that poplar trees use more water than willow trees; and salix bushes may use much more water than generally perceived (thus widely planted for soil conservation). Poplar trees use more water because they have large leaves and remain physically active till late autumn (Fig. 9a). Willow trees (locally called dry willows) use less water because they have small branches with a lower leaf area index (Fig. 9b). Salix bushes use more water because they have many branches with a large leaf area index (Fig. 10a).

Therefore, considering that water is the major limiting factor in semi-arid environments such as the Hailiutu catchment, poplar trees should not be used as wind-breaking barriers in the croplands and along the roads. Instead, willow trees are a better alternative for these purposes. For vegetating sand dunes, it seems better to select native bushes which use less water, such as Artemisia Ordosica (Fig. 10b), Korshinsk Peashrub (Fig. 11a), and Hedysarum Laeve Maxim (Fig. 11b). Other studies (Xiao et al., 2005; Zhou et al., 2011) have demonstrated that these species can be established in 
desert dunes in dry environments. However, transpiration rates of these species need to be further investigated.

\section{Conclusions}

River discharges heavily depend on groundwater in the Hailiutu River catchment. On annual average, river discharge consists of almost $90 \%$ of groundwater discharge. Measurements of hydraulic heads and temperatures as well as isotope investigations at the sub-catchment scale indicate that groundwater discharge is the most important component of river flows. Even during heavy rainfall events, the flood hydrographs consist of more than $70 \%$ of groundwater discharge.

Vegetation also depends heavily on groundwater. At the catchment scale, the vegetation cover is much denser in places where groundwater table is shallow. The Normalized Difference Vegetation Index (NDVI) decreases with the increase in the depth of the groundwater table. At the ecological research sites, it was demonstrated that both trees and bushes use groundwater for transpiration during the long dry period in spring.

Preliminary analysis of water use for different species indicates that maize crops transpire the largest amount of water. Salix bushes use much more water than generally perceived. However, water-use efficiency of other crops and plant species should be further investigated.

Under natural conditions, net groundwater recharge equals river baseflow. When groundwater is abstracted for irrigation, groundwater discharge is reduced, resulting in the reduction of river discharge. However, a relatively shallow groundwater table must be maintained for supporting groundwaterdependent vegetations.

The water resources management objectives must satisfy both the environmental water needs by vegetation and in-stream ecosystems, as well as the water use for socialeconomical development. For conservation of water resources, net groundwater recharge can be increased by reducing evaporation and transpiration by selecting more dry resistant plants for stabilising sand dunes. However, the groundwater table cannot be lowered to reduce the evaporation and transpiration since healthy vegetation must be maintained to prevent desertification. The general strategy should be to promote more dry resistant plant species with lower transpiration rates in order to reduce the total evaporation in the catchment and to maintain river discharges. Therefore, maize should be replaced by more water-use-efficient crops, while salix bushes should be replaced by dry resistant vegetation species native in the Hailiutu catchment.
Acknowledgements. This research was financed by the Netherlands government through the Asian Facility for China project "Partnership for education and research in water and ecosystems interaction" and the Chinese Honor Power Foundation, and the key laboratory of groundwater in arid and semi-arid region of China Geological Survey. The critical comments from an anonymous reviewer, T. Kanyerere, and the associate editor Dominic Mazvimavi were very useful for improving the manuscript.

Edited by: D. Mazvimavi

\section{References}

Anibas, C., Buis, K., Verhoeven, R., Meire, P., and Batelaan, O.: A simple thermal mapping method for seasonal spatial patterns of groundwater-surface water interaction, J. Hydrol., 397, 93-104, 2011.

Arriaga, M. A. and Leap, D. I.: Using solver to determine vertical groundwater velocities by temperature variations, Purdue University, Indiana, USA, Hydrogeol. J., 14, 253-263, 2006.

Boyle, J. M. and Saleem, Z. A.: Determination of recharge rates using temperature-depth profiles in wells, Water Resour. Res., 15, 1616-1622, 1979.

Bredehoeft, J. D. and Papadopulos, I. S.: Rates of vertical groundwater movement estimated from the earth's thermal profile, Water Resour. Res., 1, 325-328, 1965.

Brodie, R., Sundaram, B., Tottenham, R., Hostetler, S., and Ransley, T.: An overview of tools for assessing groundwater-surface water connectivity, Bureau of Rural Sciences, Canberra, Australia, p. 131, 2007.

Butler Jr., J. J., Kluitenberg, G. J., Whittemore, D. O., Loheide II, S. P., Jin, W., Billinger, M. A., and Zhan, X.: A field investigation of phreatophyte-induced fluctuations in the water table, Water Resour. Res., 43, W02404, doi:10.1029/2005wr004627, 2007.

Buttle, J. M.: Isotope hydrograph separations and rapid delivery of pre-event water from drainage basins, Prog. Phys. Geogr., 18, $16-41,1994$.

Constantz, J. and Stonestrom, D. A.: Heat as a tracer of water movement near streams, in: Heat as a Tool for Studying the Movement of Ground Water Near Streams, edited by: Stonestrom, D. A. and Constantz, J., US Geological Survey, Reston, Virginia, USA, 16, 2003.

Constantz, J., Stewart, A. E., Niswonger, R., and Sarma, L.: Analysis of temperature profiles for investigating stream losses beneath ephemeral channels, Water Resour. Res., 38, 1316, doi:10.1029/2001wr001221, 2002.

CropWatch: http://cropwatch.unl.edu/web/cropwatch/, last access: 20 October 2012.

Eamus, D., Froend, R., Loomes, R., Hose, G., and Murray, B.: A functional methodology for determining the groundwater regime needed to maintain the health of groundwater-dependent vegetation, Aust. J. Bot., 54, 97-114, doi:10.1071/Bt05031, 2006.

Fang, H. Y., Li, Q. Y., and Cai, Q. G.: A study on the vegetation recovery and crop pattern adjustment on the Loess Plateau of China, Afr. J. Microbiol. Res., 5, 1414-1419, 2011. 
Gleeson, T., Alley, W. M., Allen, D. M., Sophocleous, M. A., Zhou, Y. X., Taniguchi, M., and VanderSteen, J.: Towards Sustainable Groundwater Use: Setting Long-Term Goals, Backcasting, and Managing Adaptively, Ground Water, 50, 19-26, doi:10.1111/j.1745-6584.2011.00825.x, 2012.

Granier, A.: Une nouvelle méthode pour la mesure du flux de sève brute dans le tronc des arbres, Ann. For. Sci., 42, 193-200, 1985.

Hou, L., Zhou, Y., Shen, J., Bao, H., Wenninger, J., and Liu, H.: Determination of crop (maize) water use with in-situ measurements in the semiarid Hailiutu River Catchments, Northwest China, J. Agr. Water Manage, submitted, 2012.

Jin, X. M., Wan, L., Xue, Z. Q., Yu, Q. S., and Yu, Y. Q.: Research on the relationship between vegetation development and groundwater in Yinchuan Basin based on remote sensing, J. Arid Land Resour. Environ., 22, 129-132, 2008.

Jin, X. M., Schaepman, M. E., Clevers, J. G. P. W., Su, Z. B., and $\mathrm{Hu}, \mathrm{G} . \mathrm{C} .:$ Groundwater depth and vegetation in the Ejina area, China, Arid Land Res. Manage., 25, 194-199, 2011.

Jones, J. P., Sudicky, E. A., Brookfield, A. E., and Park, Y.-J.: An assessment of the tracer-based approach to quantifying groundwater contributions to streamflow, Water Resour. Res., 42, W02407, doi:10.1029/2005WR004130, 2006.

Kalbus, E., Reinstorf, F., and Schirmer, M.: Measuring methods for groundwater - surface water interactions: a review, Hydrol. Earth Syst. Sci., 10, 873-887, doi:10.5194/hess-10-873-2006, 2006.

Kranz, W. L., Irmak, S., van Donk, S. J., and Yonts, C. D.: Irrigation management for Corn, NebGuide, G1850, Institute of Agriculture and Natural Resources, University of Nebraska-Lincoln, 2008.

Lautz, L.: Estimating groundwater evapotranspiration rates using diurnal water-table fluctuations in a semi-arid riparian zone, Hydrogeol. J., 16, 483-497, doi:10.1007/s10040-007-0239-0, 2008.

Loheide, S. P., Butler, J. J., and Gorelick, S. M.: Estimation of groundwater consumption by phreatophytes using diurnal water table fluctuations: A saturated-unsaturated flow assessment, Water Resour. Res., 41, W07030, doi:10.1029/2005wr003942, 2005.

Lv, J., Wang, X.-S., Zhou, Y., Qian, K., Wan, L., Eamus, D., and Tao, Z.: Groundwater-dependent distribution of vegetation in Hailiutu River catchment, a semi-arid region in China, Ecohydrology, 6, 142-149, doi:10.1002/eco.1254, 2013.

Miller, G. R., Chen, X. Y., Rubin, Y., Ma, S. Y., and Baldocchi, D. D.: Groundwater uptake by woody vegetation in a semiarid oak savanna, Water Resour. Res., 46, W10503, doi:10.1029/2009wr008902, 2010.

Moreo, M. T., Laczniak, R. J., and Stannard, D. I.: Evapotranspiration rate measurements of vegetation typical of ground-water discharge areas in the Basin and Range carbonate-rock aquifer system, Nevada and Utah, September 2005-August 2006, US Geological Survey Scientific-Investigations Report 2007-5078, p. 36, 2007.

O’Grady, A. P., Cook, P. G., Howe, P., and Werren, G.: Groundwater use by dominant tree species in tropical remnant vegetation communities, Aust. J. Bot., 54, 155-171, doi:10.1071/Bt04179, 2006.

Santhi, C., Allen, P. M., Muttiah, R. S., Arnold, J. G., and Tuppad, P.: Regional estimation of base flow for the conterminous United States by hydrologic landscape regions, J. Hydrol., 351, 139$153,2008$.
Scanlon, B. R., Keese, K. E., Flint, A. L., Flint, L. E., Gaye, C. B., Edmunds, W. M., and Simmers, I.: Global synthesis of groundwater recharge in semiarid and arid regions, Hydrol. Process., 20, 3335-3370, doi:10.1002/hyp.6335, 2006.

Schaeffer, S. M., Williams, D. G., and Goodrich, D. C: Transpiration of cottonwood/willow forest estimated from sap flux, Agr. Forest Meteorol., 105, 257-270, 2000.

Sklash, M. G. and Farvolden, R. N.: The role of groundwater in storm runoff, J. Hydrol., 43, 45-65, 1979.

Sloto, R. A. and Crouse, M. Y.: HYSEP: a computer program for streamflow hydrograph separation and analysis, US Geological Survey Water-Resources Investigations Report 96-4040, p. 46, 1996.

Sophocleous, M.: From safe yield to sustainable development of water resources - the Kansas experience, J. Hydrol., 235, 27-43, doi:10.1016/S0022-1694(00)00263-8, 2000.

Sophocleous, M.: Interactions between groundwater and surface water: the state of the science, Hydrogeol. J., 10, 52-67, doi:10.1007/s10040-001-0170-8, 2002.

Sophocleous, M.: The science and practice of environmental flows and the role of hydrogeologists, Ground Water, 45, 393-401, doi:10.1111/j.1745-6584.2007.00322.x, 2007.

Stonestrom, D. A. and Blasch, K. W.: Determining Temperature and Thermal Properties for Heat-based Studies of Surface-water Ground-water Interactions, USGS Circular 1260, Reston, Virginia, 73-80 (Appendix A), 2003.

Sun, X. C., Jin, X. M., and Wan, L.: Effect of groundwater on vegetation growth in Yinchuan Plain, Geoscience, 22, 321-324, 2008.

Uhlenbrook, S., Didszun, J., and Wenninger, J.: Source areas and mixing of runoff components at the hillslope scale - a multitechnical approach, Hydrolog. Sci. J., 53, 741-753, 2008.

Wang, B., Yang, Q., and Liu, Z.: Effect of conversion of farmland to forest or grassland on soil erosion intensity changes in Yanhe River Basin, Loess Plateau of China, Front. Forest. China, 4, 6874, doi:10.1007/s11461-009-0015-5, 2009.

Wang, X. M., Zhang, C. X., Hasi, E., and Dong, Z. B.: Has the Three Norths Forest Shelterbelt Program solved the desertification and dust storm problems in arid and semiarid China?, J. Arid Environ., 74, 13-22, doi:10.1016/j.jaridenv.2009.08.001, 2010.

Wenninger, J., Uhlenbrook, S., Lorentz, S., and Leibundgut, Ch.: Identification of runoff generation processes using combined hydrometric, tracer and geophysical methods in a headwater catchment in South Africa, Hydrolog. Sci. J., 53, 65-80, 2008.

White, W. N.: A method of estimating ground-water supplies based on discharge by plants and evaporation from soil: results of investigations in Escalante Valley, Utah, Geological, S., US G.P.O., Washington, 1932.

Xiao, C. W., Zhou, G. S., Zhang, X. S., Zhao, J. Z., and Wu, G.: Responses of dominant desert species Artemisia ordosica and Salix psammophila to water stress, Photosynthetica, 43, 467471, doi:10.1007/s11099-005-0075-1, 2005.

Yang, Z., Zhou, Y., Wenninger, J., and Uhlenbrook, S.: The causes of flow regime shifts in the semi-arid Hailiutu River, Northwest China, Hydrol. Earth Syst. Sci., 16, 87-103, doi:10.5194/hess16-87-2012, 2012.

Yin, L. H., Hu, G. C., Huang, J. T., Wen, D. G., Dong, J. Q., Wang, X. Y., and Li, H. B.: Groundwater-recharge estimation in the Ordos Plateau, China: comparison of methods, Hydrogeol. J., 19, 1563-1575, doi:10.1007/s10040-011-0777-3, 2011. 
Yin, L., Zhou, Y., Ge, S., Wen, D., Zhang, E., and Dong, J.: Comparison and modification of methods for estimating evapotranspiration using diurnal groundwater level fluctuations in arid and semiarid regions, J. Hydrol., 496, 9-16, doi:10.1016/j.jhydrol.2013.05.016, 2013.

Zhou, Y.: A critical review of groundwater budget myth, safe yield and sustainability, J. Hydrol., 370, 207-213, doi:10.1016/j.jhydrol.2009.03.009, 2009.
Zhou, Y.: Partnership for education and research in water and ecosystem interactions, Final project report, UNESCO-IHE, Delft, the Netherlands, p. 65, 2012.

Zhou, Y.-D., Chen, S.-P., Wei-Min, S., Qi, L., and Guang-Hui, L.: Water-use strategies of two dominant desert plants along a precipitation gradient in north-western China, Chi. J. Plant Ecol., 35, 789-800, 2011. 